\title{
Planning Principles and Control Mechanisms of New Town Development in Malaysia
}

\author{
Dasimah Bt Omar \\ Faculty of Architecture, Planning and Surveying \\ Universiti Teknologi MARA \\ 40450 Shah Alam, Malaysia \\ E-mail: dasimah629@salam.uitm.edu.my
}

\begin{abstract}
There is no clear-cut definition of constitutes new towns. The notion of self-containment is rightly seen as central to many new towns and often been one of the underlying objectives. References on planning principles and control mechanisms regarding new town development in Malaysia are very limited. Therefore, the perception survey is to identify the planning principles and control mechanisms of new town development in Malaysia from the perspective of two different groups of professional town planners. The findings showed that there is an urgent need to properly define new town and to clearly spell out the planning principles and control mechanisms as to the requirements of new town development. There is a strong need for an integrated national policy, strong need for special development control mechanisms, moderately strong need for a separate format for preparing the Development Proposal Report, a moderate need for special planning standards and some support for revising the present Town and Country Planning Act so as to satisfy the new town development.
\end{abstract}

Keywords: New towns, Perception survey, Town planners, Planning principles, Control mechanisms

\section{Introduction}

The new model of urban residential development in Britain known as new town was brought into the English Planning and Development concept by the 1946 and 1965 New Towns Acts. Under this Act, New Town Development Corporations were appointed and financed by the central government to plan and create new towns (Morris:1997). The population size of the new towns varies. In Britain for example, the Reith Committee"s optimum population was 30,000-50,000 (Cullingworth and Nadin: 1994). Howard suggested 32,000 people (Hall: 1990). Building new towns is one way of coping with population growth and migration.

Malaysia has had more than three decades of experience in developing new towns. The first new town was Petaling Jaya which begun developing in 1954 to cater for the spill over of Kuala Lumpur's population. Since the implementation of New Economic Policy in the early 1970's more than 100 urban fringe new towns were developed. In 1980's the government implemented the concept of new towns in regional planning development schemes to balance up the rural economic potential and to reduce the rural-urban migration. In Malaysia the planning functions are defined in the Town and Country Planning Act (Act 172) and its subsequent amendments. However, there is no comprehensive act specifically governing the new town development. There is a need to develop planning principles and control mechanisms to be used by the federal, state and local government to regulate the activities related to new town development.

\section{Aim and Objectives}

The aim of this research is to identify the planning principles and control mechanisms of new town development in Malaysia.

The objectives are as follows:

(a) To identify the current planning principles and control mechanism of new town development from the perspective of planners from the public sector

(b) To identify the current planning principles and control mechanism of new town development from the perspective of planners from the private sector

(c) To propose new planning principles and control mechanism of new town development in Malaysia 


\section{Methodology}

Questionnaire survey was sent out to 120 town planners, 60 each to public and private town planners. These 60 public town planners were listed based on the list from the Federal Department of Town and Country Planning. While the names and addresses of 60 private practice town planners were based on the record of registered planning firms with the Malaysian Institute of Planners. Since it was intended to cover the perceptions of town planners from various parts of this country, the postal service was decided to be used in sending out and receiving of the questionnaires. The questionnaire consist of ten open-ended questions with an option of yes/no answers used, which needed further elaboration from respondents. The questions focused on the present development control measures in new town development, laws, principles and guidelines and how they defined a new town. Thirty nine per cent $(39 \%)$ of the total were returned. Out of those the respondents from the private sector totaled up to fifty one per cent (51\%) while from the public sector Forty nine per cent (49\%) questionnaires per cent were received from planners attached to the private sector. There were town planners who gave only option answers without elaborating the specific questions.

\section{Analysis}

The open-ended questions answered were analysed using segmentation factors where the perceptions were grouped into various segments based on the criteria set by the study.

\subsection{The understanding of a new town in the Malaysian context}

The first question was 'How do you perceive today's understanding of a new town in the Malaysian context?' This question was aimed at identifying the planners' interpretation of a new town as understood locally. In the Malaysian context there seem to be conflicting interpretations of a new town. The public were more exposed to the common statement of a new town in the press, as a relatively large new mixed development, close to or abutting the existing town boundary. The developers of these big scale developments used the word new town to establish an identity. On the other hand, the local authority seemed to accept and adapt it to the situation. So when this question was answered by professionals the interpretation of a new town in the Malaysian context can be defined more clearly.

In the survey form six statements relating to the understanding about a new town in the local context had been listed for the respondents to select and they were also given space to write down their opinion if none of those statements met with their perception. The selection could be more than one statement from the list. The six statements listed were as follows:

(a) a self-contained new development

(b) a large scale new development

(c) a large scale mixed new development with targeted population of about 30,000 or more

(d) any new shop house or shopping complex development

(e) any new house and business centre development

(f) any new industrial development

From the survey it shows that the new towns seem to have many interpretations. The analysis was that 53 per cent or 25 of the respondents had chosen (b) that is a large scale mixed new development as the main understanding of new towns in the local context. This opinion came from twelve public sector planners and thirteen private consultants. Another 15 or 32 per cent referred to (a) that is s a self-contained new development as the understanding of the new concept. Both the public and the private sector planners of ten each had the same understanding. As for statement (c) four planners marked it as the answer with equal opinion of two each from the public and the private sector planners.

These are the three interpretations that are considered the overall understanding of a new town in Malaysian context. The common feature of a new town as raised by these planners appears to be a large scale mixed development which must be self-contained new development with a targeted population of about 30,000 population. However, for statement (e) two respondents, one each from the two sectors had chosen it while for statement (d) only one planner from the private practice accepted it as the answer. The new industrial development or (f) does not fit to be qualified as a new town and none had chosen it.

\subsection{The overall new town development in the Malaysia}

This was intended to record the impression of those town planners with regards to new towns which had been developed throughout the Peninsular Malaysia. The planners identified for this survey were those holding the highest positions in the organizations they were attached to, be it in the government or the private consultant offices. With the experiences they had, this question had been answered by 34 per cent of them who were not satisfied with the development of new towns. Of this 34 per cent, 19 per cent of them were the public sector planners while another 15 per cent were the private sector planners. The percentage of this dissatisfaction is high among the public sector planners than the private sector planners. 
In addition to that, another 10.4 per cent of them were very dissatisfied with the situation. It was found that three respondents or 6.4 per cent from the public sector and two or 4.3 per cent from the private sector were very dissatisfied with the development. Thirteen of those planners or 27.7 per cents of them were satisfied with the new town development. Out of 27.7 per cent, 17 per cent were the private sector planners while the other 10.6 per cent were the public sector planners. However, none of respondents were very satisfied with it. The percentage of those with satisfied answer was higher in the private sector group.

Another 25.5 per cent of the respondents answered that the situation is just right in their opinion. The percentage of the private sector planners with this opinion was double that percentage of the public sector planners.

\subsection{The need for integrated national policy on new town development}

The development of new towns in this country had been treated as other land development and it has been clearly stated in the National Land Code that any decisions pertaining to land matters are taken by the State Governments. The Town and Country Planning Act 1976 is intended to ensure uniformity relating to planning in local authorities. The National Urban Policy and National Physical Plan serve as the framework outline for future urban growth in Malaysia. The National Urban Policy provides the strategic policies while the National Physical Plan provides strategic guidance on the spatial trends and patterns of development (GOM:2007). The amendment of the Town and Country Planning Act 2001 (Act A1129) provides for the setting up of the National Physical Planning Council. The main functions of this council are to include the co-ordination of development planning activities between Federal and State Authorities. This therefore can ensure sustainable use of resources to minimise impacts on the environment. The National Physical Planning Council is chaired by the Prime Minister and the Director General of Town and Country Planning is the Secretary to the council (GOM: 2007).

Consequently, this particular question was addressed in the research questionnaire to the town planners so as to have their collective suggestions about the requirements of the National Urban Policy for the regulations of the new towns. The research found that all the respondents from the public sector answered 'yes' reflecting that they agreed to the idea of the National Urban Policy on new town development while only one of the private practice planners replied negatively to this question.

\subsection{The need for a special development control mechanism}

The necessity for having control over the use of land to be in order is to ensure that land, a non renewable resource, is utilised efficiently and effectively. Development control is the daily routine job by planners especially in the local planning authority because prior to all development there is a requirement for a planning approval. Under sub-section 22(3) of the Town and Country Planning Act of 1976 (Act 172), the Local Planning Authority is the approving authority of the area for which the proposed development is intended. As for development control practice, the authority is required to grant planning permission either absolutely or subject to such condition as it thinks fit to impose, or refuse to grant planning permission for a particular submission.

The question raised to the planners was pertaining to the requirement for a special development control mechanism for new town development. Given the nature of a new town development, the development control mechanism must be designed to ensure the course of actions are considered from the early stages. The current development control mechanism does not ensure adequate integration and co-ordination at the federal, state and local government levels. Co-ordination is thus required both within the state government and with the federal government. The special development control mechanism for new town development should be able to monitor the socio economic processes and their spatial impact and to ensure national policies are fulfilled. The special development control mechanism should incorporate infrastructure, housing, facilities, industry, transportation, commerce and environment which should be linked together in an overall national planning system of a new town. The planning of a new town must be viewed as an integral part of the process of economic growth and change.

The survey found that 83 per cent or 39 respondents agreed to the need for a special development control mechanism. From this 83 per cent, 42.6 per cent were public sector planners while the other 40.4 per cent were private sector planners. The public planners were in the position of being involved directly with the development control mechanism as the administration of land and the uses permitted on that land form crucial determinants of the extent and pattern of urban development.

\subsection{The need to revise the Town and Country Planning Act of 1976 so as to satisfy the new town development}

In Peninsular Malaysia, land use planning is undertaken wholly within the provision of the Town and Country Planning Act of 1976 (Act 172) and its amendments in 1995 (Act A933), in 2001 (Act A1129) and in 2007 (Act A1313). This Act contains three basic elements towards an effective planning system which are (a) the planning administrative system, (b) the development plan system and (c) the development control system. The Act was enacted to specifically ensure more integrated and co-ordinated planning, zoning and land use management. However, there is lack of specific 
provision in the act which is related to new town development and this question was intended to gather responses regarding the need for the revision.

The analysis shows that 57.4 per cent or 27 respondents did agree to the need to revise the present act so as to satisfy the new town development. Out of these 27 planners, 17 were private practice planners while another 12 were from public agencies. Among the reasons for the revision stated by the respondents was that lack of specific provision on new town development which to them requires a separate act or sections and special approach. Another reason suggested by them was that the revision of the present act is required as the basis to regulate new centres for a more balanced and equitable growth and some proposed for a special new town act to be drafted. The planners also stated that the revision is needed to improve the present enforcement system.

However, 17 or 36.2 per cent of the total sample of planners disagreed to the revision. As for those who disagree to the proposition, 16 per cent of them stated that the present act was sufficient. Another 6 per cent of the respondents mentioned that besides the Town and Country Planning Act, there was other legislation at federal or state levels pertaining to land development which can be referred to by the State Authority upon the decision for land development approval. There were two respondents who did not answer the question and one was unsure to the requirement and wrote down the answer as unsure.

\subsection{The need for special planning standards for new town development}

Planning standards are important aids to town planners and decision makers for effective implementation and development control. Controls are normally exercised over the character and distribution of land uses, a corollary of these is effective control over intensity such as density and plot ration. 'Certain standards are set to control the physical setting of the urban land area and to contribute in ensuring safety, health, amenity welfare, convenience, efficiency and public interest' (Ratcliffe:1974:396). These planning standards are intended for open space, playgrounds, community facilities such as schools, religious centre, community hall, roads, car park, commercial areas and housing areas. Upon granting the planning permission the local planning authority would normally check on the provision of related facilities. The current practice applies population density control standards which measure the allocation of land use requirements in terms of people. The application of the common planning standards to all development of different scale and sizes will have the impact especially on the community facilities provision and other services. There is a need for special planning standards for new town development.

The study found that 61.7 per cent or 29 planners stated that there is a need for special planning standards for new town development while 36 per cent or 17 did not agree and one planner did not answer the question. Of the 61.7 per cent who agreed to the proposition, 31.9 per cent were planners from the public sector while the other 29.8 per cent were from the private sector. A total of 36 respondents cited their reasons for responding to this particular question and this comprised of 76.5 per cent of the total 47 respondents. Majority of them stated that the special planning standards were meant for new town development as to meet the current and future planned society. More so be able to adapt to the future requirements especially with regards to the information technology and globalisation era which requires special attention for infrastructure planning and development. Other reasons included were, that the existing planning standards are rigid and non-flexible, new town planning requires special innovative concepts and the different scales of the new town development need separate planning standards.

However, for those 17 respondents or 36.2 per cent who disagreed, planners from the private sector had a higher percentage as compared to those from the public sector. The main reason to disagree as stated by the planners is that the present planning standard is considered sufficient for all kinds of development Meanwhile one planner from the private sector declined to answer the question. The analysis shows that there is a need for a special planning standards for new town development.

In the United States of America they use planning standards known as land use intensity rating which takes into account wider planning field factors providing a more reliable and less variable standards (Ratcliffe:1974). In Malaysia the best example is the development of Putrajaya which was based on its special planning standards and design guidelines. The need for special planning standards for new town development is meant to create a well-integrated socially balanced community. New town development, timing, programming, magnitude and location, layout and design policy must be controlled and they should be made on a more rational basis. The special planning standards for a new town must incorporate elements of urban design and location criteria for the whole planned area. Based on the special planning standards the infrastructure and other services can be provided more efficiently and effectively and the resultant performance more accurately assesses. New town development involves design process from the earliest stages to control density, plot ratio, environment, infrastructure, public facilities and transportation networks thus providing a better and more sustainable place for living.

\subsection{The need for a separate format of Development Proposal Report for new town development}

The Town and Country Planning Act (Act 172) states in the new section 21, that the requirement for the submission of a development proposal report must be added to the documents and plans to be submitted for planning permission. The 
report should describe the present condition of the site as well as the proposed development according to a standard format applied to all types of land development (Zainuddin: 1999). The Development Proposal Report should include:

(a) a location map and a site plan

(b) particulars of land ownership and restriction

(c) a description of the land and buildings, including geology, topography, drainage and water bodies and catchment area, a survey of all trees and all forms of vegetation which may be affected by the development

(d) a land use analysis and its effect on the neighbourhood land

(e) a development proposal and layout plan stating the development concept and justification, in particular matters relating to measures for the protection and improvement of the physical environment

(f) layout plans, the details of which are specifies

(g) other matters prescribed by the local authority

The objectives of the development proposal report are to supply sufficient information about the proposed development and to ensure that all relevant matters are made available to all local planning authority, and to help the local planning authority in ensuring that its decision were based on relevant material consideration.

The study found that 66 per cent of the respondents agreed to the need for a separate format of development proposal report for new town development while the other 34 per cent disagreed to it. Out of 66 per cent who agreed to the need to have a separate format of the report, the percentage of those from the public sector was 36.2 per cent, slightly higher than those from the private sector planners group of 29.8 per cent. However, for those respondents who disagreed with the proposition, the higher percentage was the private sector planners comprising 21.1 per cent as compared to public sector planners of 12.8 per cent.

There were four main reasons as suggested by the respondents who agreed with the need for a separate development proposal report for new town development. Among those four reasons, the main one stated by them was due to the complexity and scope of the development coverage on new towns which requires a special format of the new development proposal report. Other reasons listed were to include issues on environmental impact assessment, social impact assessment and resource management so as to have more comprehensive report compared to the existing report format.

As for those who disagreed with the need for a separate development proposal report, they stated that the present format of preparing the report can be applied to all types of development and additional details can be imposed when necessary. The existing format was said to be flexible and could be adapted to all kinds of developments.

\section{Findings}

From the survey on the perception of the planners, the research found that all the related planning principles and development control mechanisms currently in practice are not fully sufficient for new town development. There is no provision on new town development in the Town and Country Planning Act (Act 172). New towns were developed based on the planning standards and guidelines applied to all other property developments. The application for planning permission and the content of the development proposal report for new town development follow similar requirement used for other developments.

For all the proposition listed in Table 1 below, the percentages of respondents supporting for the change of the planning principles and development control mechanisms as to meet the requirements of new town development ranged between 58 per cent to 98 per cent, while percentages of those disagreed to the change ranged between 2 per cent to 36 per cent.

Referring to the table, the results of the perception survey by the planners indicate that there is a need for an integrated national policy which had been suggested by 98 per cent of the respondents. The issue was supported by all respondents from the public sector while only one respondent from the private sector disagreed with it. The next issue was the need for special development control mechanism for new town development where the proposition was supported by 83 per cent of the respondents. This particular requirement was agreed upon by 87 per cent of the public planners and 79 per cent of the private sector planners.

The third important requirement suggested was the need for the separate development proposal report format for new town development as compared to a common one used for any size of development where 66 per cent of the respondents agreed for different format. The need for special planning standards for new town development was supported by 62 per cent of the respondents.

Table 1 shows that the percentage of the respondents from the public sector who supported the propositions ranged between 52 per cent to 100 per cent. The percentage of respondents from the public sector group seemed to be higher than the private sector group in all propositions except upon the issues of the need to revise the Town and Country 
Planning Act where the percentage response was lower. Their working environment may have influenced them in their decisions concerning the reasons for the requirements foe each statement.

\section{Conclusion}

This research identified the planning principles and control mechanisms of new town development from the perspectives of town planners. Based ion the analysis, a new town in the Peninsular Malaysian context could be defined as a large scale mixed development which is self contained with a targeted population of about 30,000 or more. The findings indicate the perceptions of town planners with regard to the new town development in this country. The majority of them were not satisfied with the current situation.

Therefore the research findings on this perception survey indicate the following:

(a) There is a strong need for an integrated national policy for new town development

(b) There is a strong need for a special development control mechanism

(c) There is a moderately strong need for a separate format for preparing the Development Proposal Report for a new town development

(d) There is a moderate need for special planning standards for new town development

(e) There is some support for revising the present Town and Country Planning Act so as to satisfy the new town development

\section{References}

Cullingworth, J.B. and Nadin, V, (1994) Town and Country Planning in Britain (11 ${ }^{\text {th }}$ Edition), London, Routledge

Government of Malaysia, Town and Country Planning Act (Amendment) 2007 (A1313)

Government of Malaysia, Town and Country Planning Act (Amendment) 2001 (A1129)

Government of Malaysia, Town and Country Planning Act 1976, (Act 172)

Government of Malaysia, (2007) Malaysian Townplan- Planning Many Things, Department of Town and Country Planning Peninsular Malaysia

Hall, P. (1990). Cities of Tomorrow, Oxford, Basil Blackwell

Morris, E.S. (1997). British Town Planning and Urban Design: Principles and Policies, Edinburgh, Longman

Ratcliffe, J. (1974). An Introduction to Town and Country Planning, (2 ${ }^{\text {nd }}$ Edition) London, Hutchinson. (1989 Reprinted)

Zainuddin bin Muhammad. (1999). Amendment to the Town and Country Planning Act 1976 (Act 172) and its Implications, Habitat Malaysia, Human Settlements Journal of Malaysia, Issue No. 2 Dec 1999

Table 1. Summary of responses from perception survey of town planners

\begin{tabular}{|c|c|c|c|}
\hline Planuing principles and Control Mechanism & $\begin{array}{l}\% \text { of } \\
\text { Public } \\
\text { Sector } \\
\text { Planuers }\end{array}$ & $\begin{array}{l}\text { \% of } \\
\text { Private } \\
\text { Sector } \\
\text { Planuers }\end{array}$ & $\begin{array}{l}\text { Average } \\
\%\end{array}$ \\
\hline & Yes No & Yes No & Yes No \\
\hline The need for integrated national policy & 100 & 96 & 98 \\
\hline The need for a special development control mechanism & 13 & 79 & $83 \quad 17$ \\
\hline $\begin{array}{l}\text { The need for a separate Development Proposal Report format for } \\
\text { the new town development }\end{array}$ & 22 & 42 & $68 \quad 32$ \\
\hline $\begin{array}{l}\text { The need for special planning standards for new town } \\
\text { development }\end{array}$ & 35 & $\begin{array}{ll}58 & 38\end{array}$ & 6236 \\
\hline $\begin{array}{l}\text { The need to revise the present TCP Act so as to satisfy the new } \\
\text { town development. }\end{array}$ & 39 & 33 & $58 \quad 36$ \\
\hline
\end{tabular}

